\title{
STRENGTH PROPERTIES OF CONCRETE USING PUMICE AGGREGATE AS PARTIAL REPLACEMENT OF COARSE AGGREGATE
}

\author{
Mamman Adamu Idi ${ }^{1}$, Agboola Shamsudeen Abdulazeez ${ }^{2}$, Shu'aibu Ahmed Usman ${ }^{3}$, Tapgun Justin ${ }^{4}$ \\ ${ }^{1 \& 3}$ Abubakar Tafawa Balewa University Bauchi, Nigeria \\ ${ }^{2}$ M.Tech Student, Abubakar Tafawa Balewa University Bauchi, Nigeria \\ ${ }^{4}$ College of Arts, Science and Technology Kurgwi, Shendam Plateau, Nigeria
}

ABSTRACT - The study investigated strength
properties of concrete using pumice aggregate as
partial replacement of coarse aggregate. The
study sought to determine whether pumice
aggregate can be used in structural concrete and
achieve same degree of strengths to that of
conventional aggregate concrete. What necessitated the research is the rapid population growth and increase rate of depletion of natural resources. However the rate of environmental degradation can be reduced by diversifying materials and sources of aggregates for convectional aggregates extracted from quarrying. Materials such as pumice aggregate are suitable substitute for conventional aggregate. The study was conducted through experimental research approach whereby laboratory experiments were conducted before coming up with a feasible conclusion and recommendation. DOE mixed design was adopted. Properties of aggregates such as aggregate crushing value and aggregate impact value were carried out; Slump test and compacting factor test of concrete were also carried out. Fresh and hardened concrete were obtained through outcome of experimental results and presented using tables and graphs. The study established that with pumice aggregate content the result shows slightly reduced compressive, tensile and flexural strengths as compared to the control concrete. Concrete produced with pumice as coarse aggregate meet the required strength at 28 days. Control concrete had higher compressive strength at 28 days of $1.05 \%$ compared to $5 \%$ pumice aggregate. Also control concrete had higher tensile strength at 28 days of $0.59 \%$ compared to $5 \%$ pumice aggregate in addition control concrete had higher flexural strength at 28 days of $4.41 \%$ compared to $5 \%$ pumice aggregate Concrete with pumice as coarse aggregate is optimum at $5 \%$ for all curing days which meet the required strength at 28 days but can be replaced up-to $15 \%$ aggregate replacement. This study recommends the use of admixture to improve in general the properties of concrete.

Keyword: Pumice Aggregate, Aggregate Crushing Value, Aggregate Impact Value, Slump Test Compacting Factor Test, Compressive Strength, Tensile Strength, Flexural Strength

\section{INTRODUCTION}

Concrete is a widely used construction material around the world. Concrete is a material synonymous with strength. Strength of concrete is its capacity to withstand loads tending to reduce or increase its compressive or tensile strength and longevity of this construction material for the infrastructure need of the present situation has emerged as an area of concern. Due to the vast usage of concrete in this century, concrete ingredients are in depleting stage [1].

Aggregates constitute about $70 \%$ by weight of the concrete. There is a great demand for natural aggregates as the construction activities are increasing every day. As the natural resources are decreasing every day, some alternative materials that will serve the purpose of the natural aggregates should be introduced [2]. Aggregates constitute about $70 \%$ by weight of the concrete. There is a great demand for natural aggregates as the construction activities are increasing every day. As the natural resources are decreasing every day, some alternative materials that will serve the purpose of the natural aggregates should be introduced [2]. [3] observed that an assessment of sustainable housing provision over the years in the country is constrained by factors which include but not limited to the following: Escalating high cost of building materials, dependency on imported building materials which increases the overall cost of housing units, nonacceptance of local building materials, and 
inadequate funding of research efforts of local building materials. Due to increasing cost of producing concrete using conventional materials such as cement, river sand as fine aggregate and granite as coarse aggregate in Nigeria, Researchers have been working on alternative cheap materials that would serve perfect substitutes for such materials while still meeting the set requirements for concrete in the industry [4]. In a developing country like Nigeria, the use of alternative cheaper local materials or even byproducts like the quarry dust as replacement of the coarse aggregate will greatly enhance the production of concrete with desired properties at low cost. It will drastically reduce the cost of production and consequently the cost of construction. By this, the quarry dust will be utilized effectively than allowing it waste with consequential environmental hazard [5]. Due to depletion of natural granite stone, pumice can be used as an alternative material for coarse aggregate. Pumice is a porous rounded and irregular sponge like nature formed by the action of weathering with a volcanic origin source. The suitability of pumice and volcanic materials for a particular end-use is dependent on their physical properties such as toughness, grain-size, grain-shape, density and friability [6]. However, the porous nature of the aggregate enhances interlocking sites for the cement paste to infiltrate and to form dense uniform interfacial zones between aggregate [7]. Pumice is excessively cellular, glassy lava and has the same basic composition of rhyolite. Scoria is irregular in form and generally very vesicular and has the basic composition of basalt. Scoria is usually heavier, darker and more crystalline than pumice [8]. Pumice is an extremely light, porous raw material. It can be found in many parts of the world including various developing countries with areas of past or present volcanic activities [9]. Because of their lightweight nature and insulation properties, both pumice and scoria are used as lightweight aggregate in concrete products for structural concrete, plaster aggregate and loose fill aggregate [6]. The use of light weight aggregates to produce light weight concrete has the advantage of reducing the dead weight in building structures [10]. Lightweight Aggregate Concrete (LWAC) is vital and flexible material in modern construction.

The properties of concrete produced with conventional aggregate are known which are mostly of standard while properties of concrete produced with Kasuwar Kurmi pumice deposit are yet to be assessed. The availability and affordability of pumice deposit at Kasuwar Kurmi area had necessitated this research. Therefore, this research is to assess the suitability of Kasuwar Kurmi pumice deposit as partial replacement for coarse aggregate in concrete in order to, determine the optimum percentage replacement of conventional aggregate with nonconventional aggregate of pumice deposit in Kasuwar kurmi Kano state. Therefore the objective of this study sought to the strength properties of concrete using pumice aggregate as partial replacement of coarse aggregate.

\section{MATERIALS AND METHODS}

All the materials used for laboratory experiment were procured from the immediate environment. The relevant standards were used in the process of conducting the experiments.

2.1 Materials The materials for this study included, coarse aggregate fine aggregate, Cement, pumice aggregate, acrylic acid and water. Pumice was gotten from kasuwar kurmi in Kano state, Nigeria, and crushed with hammer to determine the size of the coarse aggregate needed for this work. It was soaked in water for 48 hours after which it was air dried for an hour under shed. The coarse aggregate was obtained from a quarry site within Bauchi metropolis. The fine aggregate was obtained from Bayara Riverflow in Bauchi state. The ordinary Portland cement is the brand of Dangote of Grade 42.5 which was procured from vendors within Bauchi metropolis.

\subsection{Aggregate Crushing Value Test}

In determining the aggregate crushing value for both pumice aggregate and normal coarse aggregate, the weight of the empty mould was determined and recorded as $\mathrm{W}_{1}$, the material which were sieved using sieve $14 \mathrm{~mm}$ and $10 \mathrm{~mm}$ that is, materials passing $14 \mathrm{~mm}$ sieve and retained on $10 \mathrm{~mm}$ sieve size were poured in the mould, tam with 25 struck of $16 \mathrm{~mm}$ rod in two layer and was weight and recorded as $\mathrm{W}_{2}$, after that the mould and the material were placed on the machine and the plunger was placed on the leveled material in the mould and was crushed between 1015 minutes. The crushed sample was then brought out and sieved with a sieve of $2.36 \mathrm{~mm}$, the material retained and the one passing were weight and recorded as $\mathrm{W}_{3}$ and $\mathrm{W}_{4}$ respectively.

The aggregate crushing value ACV was determined using equation 1 .

$\frac{W 4}{W 2-W 1} \times 100 \ldots \ldots \ldots \ldots$

\subsection{Aggregate Impact Value Test}

This test is for aggregate in concrete that undergoes impact as in runways and airport. Materials passing through $14 \mathrm{~mm}$ and retained as 


\section{International Journal of Engineering Applied Sciences and Technology, 2020 Vol. 4, Issue 11, ISSN No. 2455-2143, Pages 519-525 \\ Published Online March 2020 in IJEAST (http://www.ijeast.com)}

$10 \mathrm{~mm}$ was filled in the standard mould in 2 layers, each layer was tamped with 25 strokes of an iron rod. A hammer weight $14 \mathrm{~kg}$ is dropped from a height of $380 \mathrm{~mm} 15$ times and the resulting material is sieve through a $2.36 \mathrm{~mm}$ sieve. The percentage fine is the aggregate impact test value. This was determined using equation 2.

$\frac{W 4}{W 2-W 1} \times 100$

2.4 Workability Tests of the wet Concrete Slump test and compaction factor test was conducted using the relevant cone for measurements. The tests were conducted in accordance with [11].

2.5 Density Test: This was carried out prior to crushing of the concrete specimen. At the end of each curing period, the concrete specimens were weighed using an electric weighing machine balance. Density is calculated as mass of concrete specimen in $(\mathrm{kg})$ divided by volume of concrete cube $\left(\mathrm{m}^{3}\right)$ and expressed in $\mathrm{kg} / \mathrm{m}^{3}$.

2.6 Compressive Strength Test of concrete: The compressive strength test was conducted in accordance with [12]. The 1: 1.8: 2.3 mix ratios were adopted using a water cement ratio of 0.5 . The ratio of pumice was that of coarse aggregate and acrylic acid was that of percentage of cement. The cubes were cast and cured for 7 days, 14 days and 28 days respectively. For each mix, 3 cubes were crushed to obtain the average strength of the concrete samples. The compressive strength is the ratio of the weight of cube and the cross sectional area.

2.7 Split Tensile Strength Test of Concrete: In the determination of tensile strength of concrete, the procedures as in accordance with [13] were followed. The split tensile strength Fct in N/mm ${ }^{2}$ was computed using equation 1.

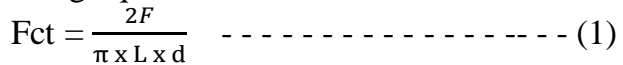

$\mathrm{F}$ is the maximum load in $(\mathrm{KN})$
$\mathrm{L}$ is the average measured length in (mm)

$\mathrm{d}$ is the average measured diameter in $(\mathrm{mm})$

The spilt tensile strength is measured is expressed to the nearest $0.05 \mathrm{MPa}$.

2.8 Flexural Strength Test of Concrete: In the determination of flexural strength of concrete beams, the procedures as in accordance with [14] were followed.

\section{RESULTS AND DISCUSSION}

3.1 Aggregate Crushing Value: The results of the crushing as presented in Table 1 and Table 2 shows that value for coarse aggregate is $21.1 \%$ and that of pumice aggregate is $28.4 \%$ respectively.

3.2 Aggregate Impact Value: The results of the impact test as presented in Table 3 and 4 shows that value for coarse aggregate is $16.11 \%$ and that of pumice aggregate is $28.63 \%$ respectively.

3.3 Workability: The Slump test results are presented in Figure 1. The slump values increased with increase ratio of pumice aggregate content except for 5\% replacement which retains same value as that of $0 \%$ replacement of aggregate. All the values fall within the low range of slump $(35 \mathrm{~mm}-$ $75 \mathrm{~mm}$ ) in accordance with [11]. According to [15], $0 \%, 5 \%$ and $10 \%$ replacement was in the S1 classification $(10 \mathrm{~mm}-40 \mathrm{~mm})$ while the remaining were in the $\mathrm{S} 2$ classification $(50 \mathrm{~mm}-90 \mathrm{~mm})$. The result of the Compacting factor test is shown in Figure 2 . The value of $0 \%$ pumice aggregate has the highest compacting factor value with 0.93 while $5 \%$, $10 \%, 15 \%$ and $20 \%$ has values of $0.92,0.92,0.88$ and 0.86 respectively. The Compacting factor values can be categorized as very low (0.78), low (0.85), medium (0.92) and high (0.95) in accordance with Building research establishment and specified by [16]. 
International Journal of Engineering Applied Sciences and Technology, 2020

Vol. 4, Issue 11, ISSN No. 2455-2143, Pages 519-525

Published Online March 2020 in IJEAST (http://www.ijeast.com)

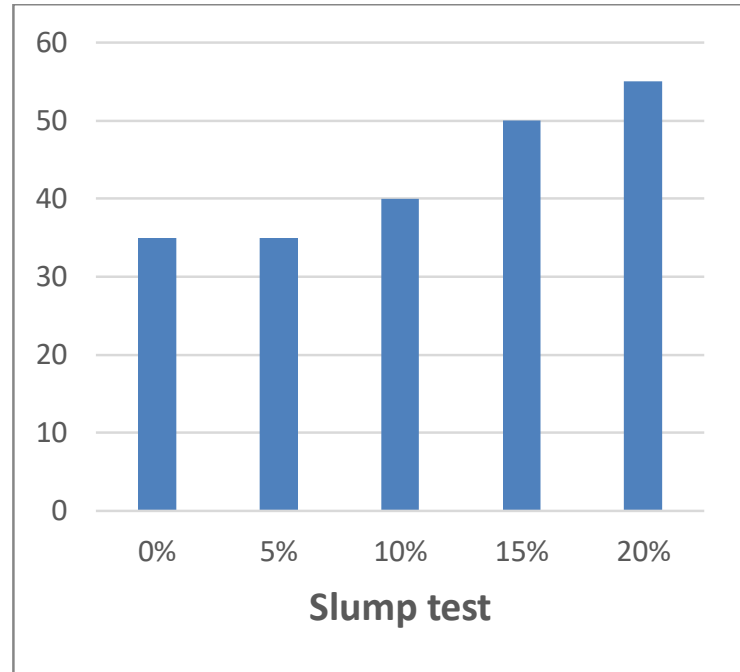

Figure 1: Slump test

3.4 Density of the Concrete: The results of the density test are shown in Figure 3,4 and 5. The densities of concrete cubes at $0 \%$, shows higher densities at 28 days period of curing more than $5 \%$ and $10 \%$ replacement level, while the density of $15 \%$
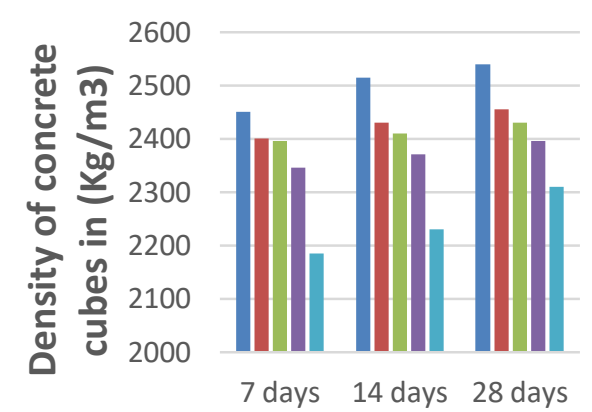

- $0 \%$

$5 \%$

$10 \%$

- $15 \%$

$20 \%$

Hydration Periods

Figure 3: Density of Concrete Cubes against Curing Period

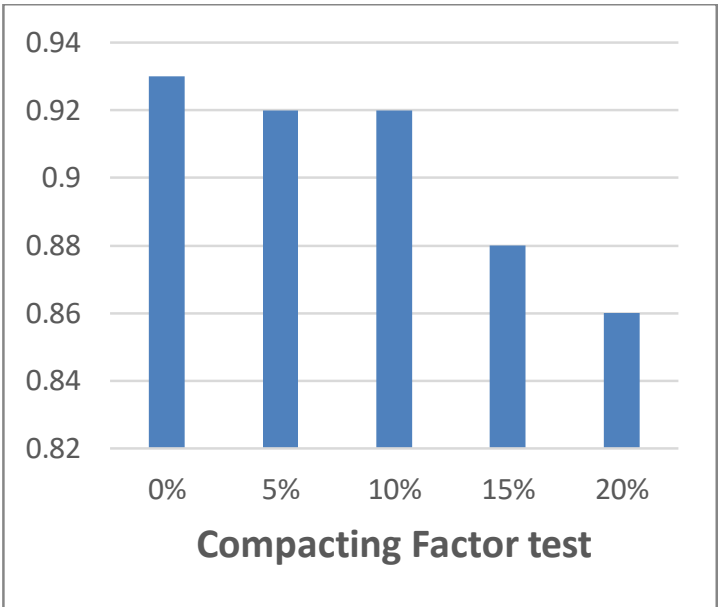

Figure 2: Compacting Factor test

and $20 \%$ show decreased in density of the cubes specimen as compared to 5\%,10\% and the control concrete specimen.

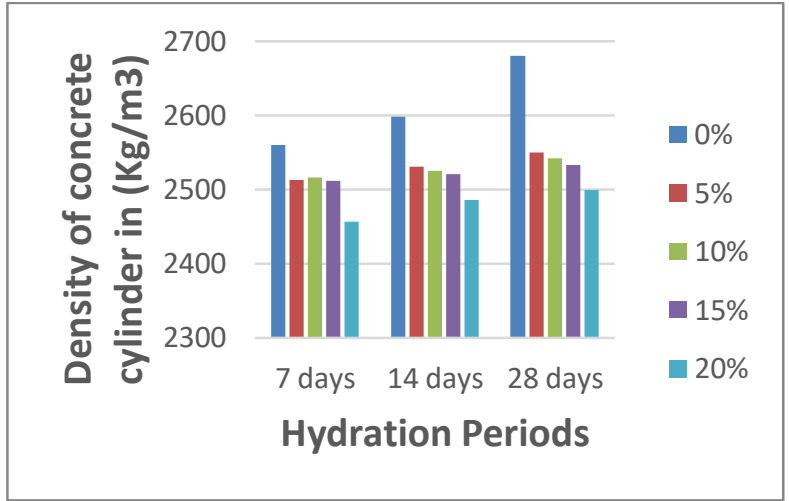

Figure 4: Density of Concrete Cylinder against Curing Period

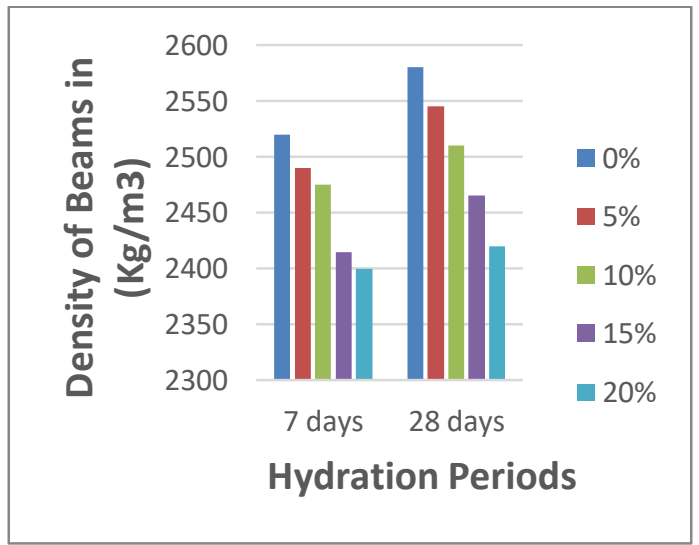

Figure 5: Density of Concrete Beams against Curing Period 
3.5 Compressive strength of the Concrete: The results of the compressive strength test are shown in Figure 6. At 7 days the result shows maximum compressive strength with $0 \%$ aggregate replacement, 5\% aggregate replacement with pumice aggregate showed increased strength than other aggregate replacement level but reduction in strength index of $1.13 \%$ as compared to $0 \%$ aggregate replacement, while the at $5 \%$ and $10 \%$ pumice aggregate replacement shows improvement in strength index. Furthermore at 28 days curing the result of the experimental study shows that $0 \%$ aggregate replacement of with pumice aggregate indicate higher strength than all other replacement. However optimum aggregate replacement was observed at 5\% replacement of aggregate but $10 \%$ and $15 \%$ aggregate shows promising result.

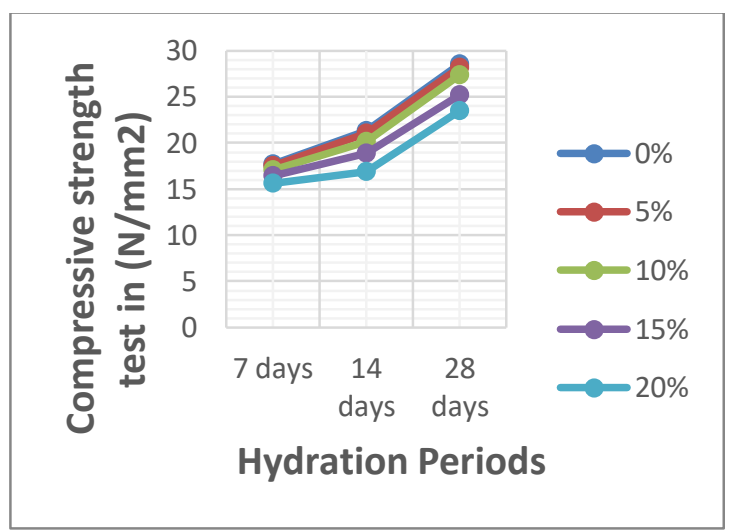

Figure 6: Compressive strength of Concrete

3.6 Split tensile strength of the Concrete: The results of the tensile strength test are shown in Figure 7. The maximum tensile strength was observed at $0 \%$ pumice aggregate replacement; however there was significant strength increase at 5\% and 10\%. The 5\% and $10 \%$ replacement ratios show high strength but less than the plain concrete specimen. The optimum replacement was observed at 5\% level, however aggregate can be replaced up-to $15 \%$ due to observed strength increase index.

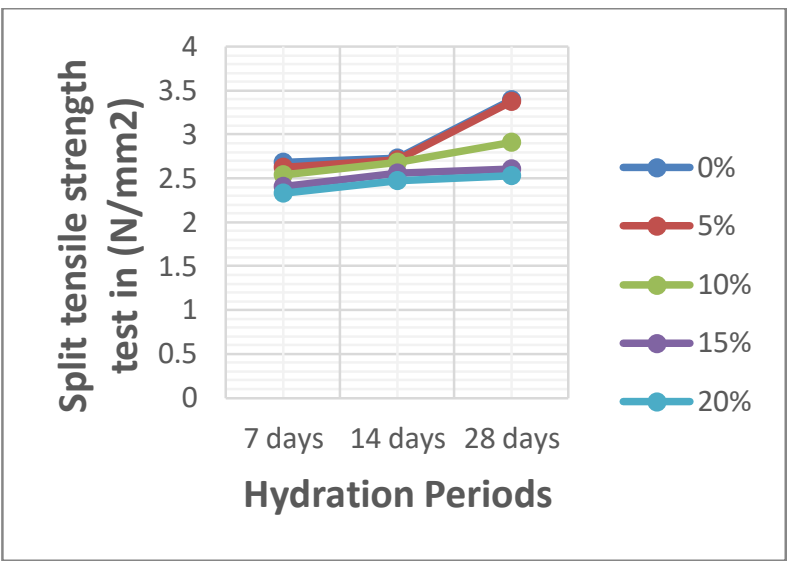

Figure 7: Split Tensile Strength of Concrete

3.7 Flexural strength of the Concrete: The results of the compressive strength test are shown in Figure 8. The flexural strength was tested at 7 and 28 days only. At 7 days the maximum strength of the beams was observed at $0 \%$ aggregate replacement level, while at 5\% replacement level shows significant strength increase than all other replacement level, in addition $10 \%$ and $15 \%$ replacement level has same strength index but less than 5\% and the control, while at 28 days the maximum strength was observed at $0 \%$ replacement level, while $10 \%$ and $15 \%$ shows increased strength but less than $5 \%$ replacement level and control at $0 \%$. The 5\% aggregate replacement was slightly less than control specimen. However the result shows that the optimum replacement level of pumice aggregate is at $5 \%$ but $10 \%$ and $15 \%$ shows significant and promising result.

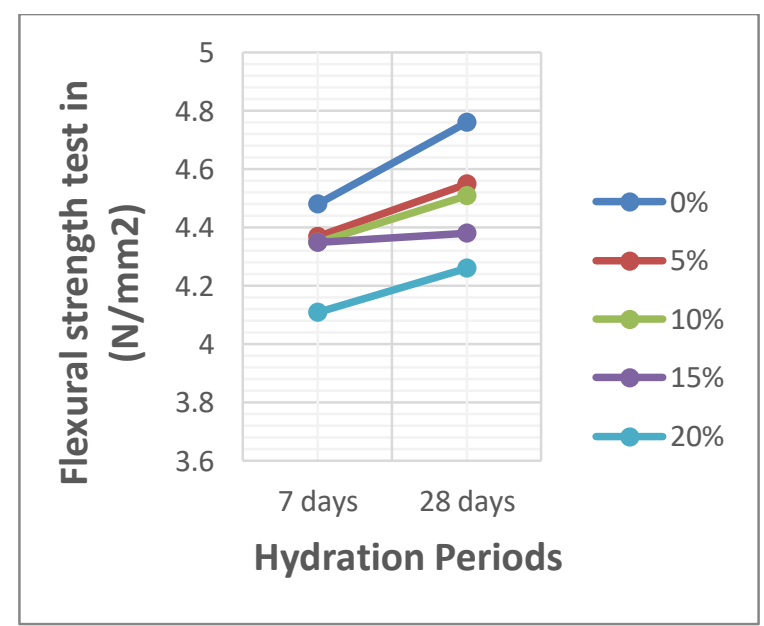

Figure 8: Flexural Strength of Concrete

\section{CONCLUSION}

The workability of the fresh mixes fell within the low and medium classifications. The maximum 
compressive strength was observed at $0 \%$ replacement level for all curing ages. The compressive strengths at 5\% replacement level of aggregate shows significant increase in strength of concrete although less than that of the plain concrete specimen. The result indicates that all replacement levels meet the requirement of BS EN 206-1: 2000 for class $\mathrm{C} 25 / 30$ and $\mathrm{C} 20 / 25$ respectively for heavy weight concreting and LC25/28 and LC20/22 respectively for light weight concreting. In conclusion, while the maximum tensile strength was also observed at $0 \%$ aggregate replacement level, the optimum replacement level of pumice aggregate was at $5 \%$. The maximum flexural strength was also the plain concrete, however all replacement levels shows improve tensile strength up-to $20 \%$. The study suggests that pumice aggregate could be replaced upto $15 \%$ with $5 \%$ represent the optimum replacement level. The density related values shows higher density at $0 \%$ replacement level, also 5\% replacement indicate high density but less than the plain concrete, in addition $20 \%$ replacement level shows reduced density. The research concluded that the pumice aggregate shows optimum replacement at $5 \%$ which can produce very strong concrete but can be used up-to $15 \%$. Further study are recommended on other properties such as water absorption capacity, abrasion resistance, durability on concrete made with pumice aggregate. Admixtures may be added to improve performance, using different mixes and altering water cement ratio also recommended.

Table 1: Aggregate Crushing Value for Coarse aggregate

\begin{tabular}{llll}
\hline \multicolumn{1}{c}{ Description } & Sample & & \\
& A & B & C \\
\hline Weight of empty mould $\mathrm{W}_{1}(\mathrm{~kg})$ & 12.10 & 12.10 & 12.10 \\
Weight of mould + sample $\mathrm{W}_{2}(\mathrm{~kg})$ & 15.15 & 15.17 & 15.25 \\
Weight of sample Retained $\mathrm{W}_{3}(\mathrm{~kg})$ & 2.45 & 2.42 & 2.44 \\
Weight of sample passing. $\mathrm{W}_{4}(\mathrm{~kg})$ & 0.60 & 0.65 & 0.71 \\
$\mathrm{ACV}=\frac{W 4}{W 2-W 1} \times 100(\%)$ & 19.67 & 21.17 & 22.54 \\
Average ACV $(\%)$ & 21.1 & & \\
\hline
\end{tabular}

Table 2: Aggregate Crushing Value for Pumice Aggregate

\begin{tabular}{llll}
\hline \multicolumn{1}{c}{ Description } & Sample & & \\
& A & B & C \\
\hline Weight of empty mould $\mathrm{W}_{1}(\mathrm{~kg})$ & 12.10 & 12.10 & 12.10 \\
Weight of mould + sample $\mathrm{W}_{2}(\mathrm{~kg})$ & 16.15 & 16.20 & 16.35 \\
Weight of sample Retained $\mathrm{W}_{3}(\mathrm{~kg})$ & 2.91 & 2.95 & 3.02 \\
Weight of sample passing. $\mathrm{W}_{4}(\mathrm{~kg})$ & 1.14 & 1.15 & 1.23 \\
ACV $=\frac{W 4}{W 2-W 1} \times 100(\%)$ & 28.15 & 28.05 & 28.94 \\
Average ACV $(\%)$ & 28.4 & & \\
\hline
\end{tabular}

Table 3: Aggregate Impact value for Coarse aggregate

\begin{tabular}{llll}
\hline \multicolumn{1}{c}{ Description } & Sample & & \\
& A & B & C \\
\hline Weight of empty mould $\mathrm{W}_{1}(\mathrm{~kg})$ & 2.55 & 2.55 & 2.55 \\
Weight of mould + sample $\mathrm{W}_{2}(\mathrm{~kg})$ & 3.15 & 3.15 & 3.21 \\
Weight of sample Retained $\mathrm{W}_{3}(\mathrm{~kg})$ & 0.51 & 0.50 & 0.55 \\
Weight of sample passing. $\mathrm{W}_{4}(\mathrm{~kg})$ & 0.09 & 0.10 & 0.11 \\
AIV $=\frac{W 4}{W 2-W 1} \times 100(\%)$ & 15.00 & 16.67 & 16.67 \\
Average AIV $(\%)$ & 16.11 & & \\
\hline
\end{tabular}

Table 4: Aggregate Impact Value for Pumice aggregate

\begin{tabular}{llll}
\hline \multicolumn{1}{c}{ Description } & Sample & & \\
& A & B & C \\
\hline Weight of empty mould $\mathrm{W}_{1}(\mathrm{~kg})$ & 2.55 & 2.55 & 2.55 \\
Weight of mould + sample $\mathrm{W}_{2}(\mathrm{~kg})$ & 3.48 & 3.51 & 3.49 \\
Weight of sample Retained $\mathrm{W}_{3}(\mathrm{~kg})$ & 0.67 & 0.69 & 0.66
\end{tabular}


Weight of sample passing. $\mathrm{W}_{4}(\mathrm{~kg})$

$\mathrm{AIV}=\frac{W 4}{W 2-W 1} \times 100(\%)$

0.26

27.96

28.63

Average AIV (\%)
0.27

28.13
0.28

29.79

\section{ACKNOWLEDGEMENT}

All praise to almighty GOD and CREATOR, the most merciful, the one that spare our lives up to this moment and also gives us the ability and courage to carry out this work from inception to successful completion. Appreciation also goes to building department concrete laboratory technologist Mal. Aliyu Jungudo and Civil Engineering concrete lab technologist Mallam Tasiu Ibrahim of ATBU Bauchi for their help, friendliness and tolerance during the experiment.

\section{REFERENCES}

1. Rajendra D., and Gokulram H. (2017). Effect of Strength Properties on Concrete by Partial Replacement of Coarse Aggregate with Waste Cuddapah Stones. International Journal of Engineering Trends and Technology, 4 (2), (pp.56-74).

2. Sanjeev K., Ramesh C G., Blessen S. T., and Priyansha M. (2016). Aggregate Replacement and Its Usefulness in Cement Concrete for Sustainable Development. A Study on Rubber, Jarosite and Sandstone Aggregates.

3. Ayedun C. A., and Oluwatobi A. O. (2011). Issues and Challenges Militating against the Sustainability of Affordable Housing Provision in Nigeria. Society for Business and Management Dynamics Business Management Dynamics. 1 (4), (pp. 01-08).

4. Salau M. A., Busari A. O., (2015). Effect of Different Coarse Aggregate Sizes on the Strength Characteristics of Laterized Concrete, 2nd International Conference on Innovative Materials, Structures and Technologies IOP Publishing IOP Conf. Series: Materials Science and Engineering.

5. Aginam C. H., Nwakaire, C., and Onah, B. C. (2016). Quarry Dust as a Partial Replacement of Coarse Aggregates in Concrete Production. Journal of Mechanical and Civil Engineering. 13 (1), (pp. 65-73). www.iosrjournals.org

6. Evans E. J., Inglethorpe D. J. S., Wetton D. P., Bailey D. E., Bongole Z., Kagasi J., and Mathor S. J. (1999). E valuation of Pumice and Scoria
Samples from East Africa as Lightweight aggregate. British Geological Survey "Mineralogy and Petrology Technical Report".

7. Lau I., Setunge S., and Gamage N. (2014) Properties of Concrete Using Scoria Lightweight Aggregate Concrete 23rd Australasian Conference on the Mechanics of Structures and Materials Byron Bay, Australia.

8. Aho I. M. and Uungwa S. J, (2015) Engineering Properties of Scoria Concrete as a Construction Material. Global Journal of Engineering Research $14 \quad$ (2) (pp. 59-63). www.globaljournalseries.com

9. Taba A. A, (2015). Assessment of Pumice and Scoria Deposits in Dhamar - Rada' Volcanic

Field SW-Yemen, as a Pozzolanic Materials and Lightweight Aggregates International Journal of Innovative Science, Engineering \& Technology. 2 (9), (pp. 13-21). www.ijiset.com

10. Ndububa, E. E., Aho, M. I and Utsev, J. T. (2009). An Investigation of Bamboo Nut as an Aggregate in Concrete. Nigerian Journal of Engineering Research and Development. 8, (2), (pp. 14-19).

11. British Standard, (1983). Testing concrete; Method for determination of slump. BS 1881102, BSI, Linfordwood, Milton Keynes MK14 6LE, U.K

12. British Standards Institution 1970. BS 1881, Part, Methods of Testing Concrete Strength, BSI London.

13. BS1881 - 117: 1983. Testing Concrete - Method for determination of tensile splitting strength. British Standards Institute, London

14. British Standards, BS 1881 Part 4, Method of Testing Concrete for Strength (London: British Standard Institution BSI, 1970).

15. EN206-1. (2000). Concrete - Part 1: Specification, performance, production and conformity. Brussels: European Committee for Standardization.

16. Neville, A.M. and Brooks, J.J., (2010). Concrete Technology. 2nd edition. Long man Group United Kingdom Limited, (pp. 30-269). 